\title{
FEEDING SUGAR BEET TOPS SILAGE FOR SHEEP: 1 - IN SUMMER
}

\author{
T.A.A. Deraz ${ }^{1}$, A.A. Khir ${ }^{1}$, A.I.A. Suliman ${ }^{1}$, O. Abdel-Salam ${ }^{1}$ and A.O. Elashhab ${ }^{2}$ \\ ${ }^{1}$ Animal Nutrition Department, Animal Production Research Institute, , Giza, Egypt. \\ ${ }^{2}$ Agriculture Ingenear Research Institute, Giza, Egypt.
}

(Received 10/12/2015, Accepted 6/1/2016)

\section{SUMMARY}

$\mathrm{T}$

This study was conducted to investigate the growth performance of lambs fed sugar beet tops silage (SBTS) with concentrate feed mixture CFM. Forty growing male lambs (20 Frafra and 20 saidi weight $20.19 \mathrm{~kg}$ as average) were used in feeding trail. Animals were randomly divided into five similar groups according to their live body weight beside twenty mature rams ( $45 \mathrm{~kg}$ live body weight) were used in digestibility trails. Each groups were fed one of the following diet. (T1), CFM +Wheat Straw control, (T2), CFM + SBTS supplemented with 0.25 urea $/ 100 \mathrm{~kg}$ dry matter of silage unchopped), (T3), CFM + SBTS supplemented with 0.25 urea /100 kg dry matter of silage chopped), (T4), CFM + SBTS supplemented with 0.5 urea $/ 100 \mathrm{~kg}$ dry matter of silage un-chopped), (T5), CFM + SBTS supplemented with 0.5 urea $/ 100 \mathrm{~kg}$ dry matter of silage chopped). CFM were offered as $3 \%$ of live body weight for all groups, while roughages were fed ad lib. Control $\mathrm{T} 1$ had higher $(\mathrm{P}<0.05)$ digestibility in $\mathrm{CP}$, CF, EE and TDN compared with treatments containing ureated SBTS chopped or un-chopped, but diets ureated with $0.25 \%$ urea chopped or unchopped was better in digestibility than those ureated with $0.5 \%$ urea. Rations containing $0.25 \%$ urea chopped or un-chopped(T2 andT3) were the best $(\mathrm{P}<0.05)$ digestibility in $\mathrm{OM}$, NFE and digestible crude protein (DCP) than rations T4,T5 and control. The values of total nitrogen intake (TNI), fecal nitrogen (FN), urinary nitrogen(UN), total nitrogen excretion(TNE), nitrogen balance(NB) and nitrogen absorption $(\mathrm{NAB})$ in control treatment lower $(\mathrm{P}<0.05)$ than other treatments. Total gain and daily gain were reicorded by the rations contain SBTS( U .0250\% ) higher than rations contain SBTS (U.0.5\%) and control ration. This diferences were insignificant. The significant $(\mathrm{P}<0.05)$ higher DM and TDN consumed by lambs fed control ration (T1),but feed intake as DCP has lower than other treatments . Lambs fed T2 and T3, showed the best conversion as DM and TDN, compared with those fed (T1),(T4) and(T5). Therefore, the lowest feed cost and the best weight gain equal the best revenue and better economic efficiency which showed by lambs fed diets containing ureated sugar beet tops T2 flowed by T3, T4, T5 and T1.

Keywords: silage, performance, digestibility, sugar beet tops, urea, chopped and unchopped.

\section{INTRODUCTION}

In Egypet, the total planted area of sugar beet was about 504 thousand faddans (Agriculture Economics , 2015). The sugar beet leaves is the one of the most important by products of the sugar beet production after harvest. Beet tops can be used as silage. Tops are an excellent source of protein, vitamin A and carbohydrates. Tops are equal to alfalfa haylage or corn silage for sheep . Beet top silage is best fed in combination with other feeds. Tops should be windrowed in the field and allowed to wilt to 6065\% moisture befor ensilage (Stanacev Vidica 2002 ; B "ohme et al., 2001 ). Sugar beets produce about15 tons/ feddan of roots and 4 tons/ feddan of TDN in the tops. Beet top silage is best fed in combination with other feeds. So, ensiling of sugar beet tops may contribute in solving some problems concerning resources of animal feeding, especially in summer season and minimize the pollution. It may offer a reduction of feed coast and minimize quantities of expensive concentrate feedstuffs used in animal feeding( Mohi El-Din,1998 and Bendary et al 1999). Moreover it may after a significant reduction of feed cost as well as reduction of using concentrate feed mixture for lactating cows(Bendary and younis, 1997) and lambs (Ghanem et al., 2000) or replacing fresh berseem in ration lactating cows.(Ahmed et al.,2003) Therefore silage can form the complete ration for bulls if mineral and vitamin supplementation are available. Supplemental protein will often be required when grass silage are fed( Haustein,2003). The aim of this study was to investigated the effect of feeding different treatments on sugar beet tops silage on nutrient digestibility, growth performance, economic efficiency of growing sheep. 


\section{Deraz et al.}

\section{MATERIALS AND METHODS}

The current study was carried out at Mallawi, Animal Production Research station belonging to Animal Production Research Institute, Agriculture Research Center, Ministry of Agriculture, Egypt. Digestibility trails were conducted to calculate nutritive values, nitrogen balance. performance and economic study were also studied.

\section{Silage preparation}

Sugar beet tops (SBT) was collected from suger beet fildes at the harvesting time and wilted to diminish the moisture content to about $70 \%$ befor ensilage. Wilted SBT chopped or unchopped were ensileang in stack of $2 \times 1.5 \times 1.75$ meters. For both four silages $5 \%$ molasses and $1.5 \%$ lime stone were added every bunker. Urea was used by 0.25 or $0.50 / 100 \mathrm{~kg}$ dry matter of silage. Silages compressed by a workers feet, then covered with plastic sheet, hard presed with $30 \mathrm{~cm}$ of soil layer and ensild for 12 weeks .

\section{Feeding trail}

Fourty growing male lambs (20 Saidi lambs + 20 Frafra lambs), with 6 months age and $20.10 \pm 0.39$ $\mathrm{kg}$ live body weight (LBW) were distributed into five simlar groups $(\mathrm{n}=$ eight each). From the pervious studies on sugar beet tops silage pointed that a good quality feeding values, so, treatments were :

$\mathrm{T}_{1}$ (control) 3\% CFM (concentrate feed mixture)+ W.S.(wheat straw) ad lib.

$\mathrm{T}_{2} 3 \%$ CFM +unchopped SBTS $0.25 \%$ urea\} 1 0 0 \mathrm { Kg } \text { DM SBTS ad lib . }

$\mathrm{T}_{3} 3 \% \mathrm{CFM}+$ chopped SBTS $0.25 \%$ urea $100 \mathrm{Kg}$ DM SBTS ad lib.

$\mathrm{T}_{4} 3 \% \mathrm{CFM}+$ unchopped SBTS $0.5 \%$ urea $\backslash 100 \mathrm{Kg}$ DM SBTS ad lib .

$\mathrm{T}_{5} 3 \% \mathrm{CFM}+$ chopped SBTS $0.5 \%$ urea $\backslash 100 \mathrm{Kg}$ DM SBTS ad lib .

Rations offered twice daily equal portions at 8.00 am and $4.00 \mathrm{pm}$. Water was freely available to lambs . Lambs were weighted biweekly in the morning befor feeding and drinking . The duration of experimental trial equal 18 weeks.

\section{Digetibility trails}

A total of 20 mature rams with an average $45 \mathrm{Kg}$ live body weight were applied in digestion trails four animals for each treatment. Each trail lasted 21 days in which,14 days as a preliminary period and seven days for faces and urine collection. Rations offered twice daily( 8.00 am and 4.00pm) into two equal portions. Fresh water was made available all the time. Faces were collected and weighted daily and sample of $10 \%$ of total daily faces were taken for drying at $60^{\circ} \mathrm{c}$ for 24 hours. At the end of the collection period, $5 \%$ of the individual acidified daily urine sample were pooled and subsamples were subjected for urine determination.

\section{Economical evalution}

Economical evalution for the tested diet assuming that the price of one $\mathrm{kg}$ of live body weight of the lambs was 22.00 Egyptian pound (LE). The price of one $\mathrm{kg}$ DM of CFM, wheat straw and ureated SBTS ( 0.25 or 0.50 urea) chopped or unchopped were $2.50,1.10,0.70,0.80,0.80$ and 0.90 LE respectively. The experiment was terminted when lambs reached LBW. (40- $45 \mathrm{~kg})$.

Analysis of feed, feces and nitrogen of urine samples were carried out according to A.O.A.C. (1999).

\section{Statstical analysis}

Data are expressed as mean $\pm \mathrm{SE}$, statistical analysis was performed using one way ANOVA. The general linear model (GLM) was applied to test the differences among the five experimental diets . Pvalues less than 0.05 were considered to be statistically significant (SAS. Institute, 2003). Duncan's test was used to examine the significant degrees among means (Duncan's 1955).

The statistical analysis was calculated using the following equations : Yijk $=\mu+\mathrm{Ti}+$ eijk

Where : Yijk= Experiment observations; $\mu=$ The over all mean; $\mathrm{Ti}=$ The effect of dietary treatments, eijk= The experimental error. 


\section{RESULTS AND DISCUSSION}

\section{Proximate Analysis}

Chemical composition on dry matter basis of individual feedstuffs and the calculated composition of experimental rations are shown in Table (1). Data revealed that the average contents of $\mathrm{CP}$ and ash were higher in sugar beet tops silage compared with CFM the figures were (15.25\% and 30.40\% vs 14.02 and $11.60 \%$ respectively). While the average contents of OM and NFE \% were high in CFM compared with SBTS (88.40 and $57.70 \%$ vs 69.60 and 37.10) respectively. So, that the contents of CP and ash in experimental rations were affected by urea and leaves of sugar beet leaves. It is quite accepted that the leaves contain greater portions of CP and lesser portions of CF (Taie 1998 and Suliman 2001). Silages showed low percentage of NFE than CFM. Silage characterized had lower content of NFE, but higher content of $\mathrm{CF}$ as a source of structural carbohydrate than CFM (MARSS, 1997). Moreover some NFE were fermented through ensiling. These results are agreed with those reported by Suliman et al. (2004 and 2013). Average ash percent for SBTS was 30.4\%, this value was in accordance with those reported by Bendary et al. (1996) they found that value of ash in SBTS was $30.21 \%$. The high ash content in sugar beet leaves could be explained by soil contamination (Ximena Valderrama and Rene Anrique, 2011) .

Table (1): Chemical composition of tested feedstuffs and experimental rations used in feeding lambs .

\begin{tabular}{lccccccc}
\hline \multirow{2}{*}{ Item } & DM\% & \multicolumn{7}{c}{ Chemical analysis on DM basis } \\
\cline { 3 - 7 } & & OM & CP & CF & EE & NFE & Ash \\
\hline CFM & 93.35 & 88.40 & 14.02 & 14.07 & 2.61 & 57.7 & 11.60 \\
W.S. & 89.00 & 89.40 & 2.39 & 40.30 & 1.56 & 45.15 & 10.60 \\
SBTS. U(0.25) UN & 28.59 & 69.10 & 15.00 & 14.90 & 2.23 & 36.97 & 30.90 \\
SBTS. U(0.25) CH & 27.78 & 69.80 & 15.23 & 15.05 & 2.10 & 37.42 & 30.20 \\
SBTS. U(0.50) UN & 30.16 & 69.50 & 15.48 & 14.37 & 2.02 & 37.63 & 30.50 \\
SBTS. U(0.50) CH & $31.66 \mathrm{~s}$ & 70.00 & 15.28 & 14.60 & 2.36 & 37.76 & 30.00 \\
Rations & & & & & & & \\
T1 & & 88.62 & 11.43 & 19.90 & 2.38 & 54.91 & 11.38 \\
T2 & & 80.89 & 14.40 & 14.39 & 2.46 & 53.64 & 15.11 \\
T3 & & 80.62 & 14.56 & 14.50 & 2.37 & 53.19 & 15.38 \\
T4 & & 81.22 & 14.58 & 14.19 & 2.39 & 54.06 & 14.78 \\
T5 & & 80.09 & 14.59 & 14.30 & 2.50 & 52.70 & 15.91 \\
\hline
\end{tabular}

The concentrate feed mixture (CFM) consisted of cotton seed meal 8\%, rice gluten meal 7\%, soybean meal 3\%, wheat bran $21 \%$, rice bran $18 \%$, ground maize $25 \%$, molasses $15 \%$, lime stone $2.5 \%$ and salt $0.5 \%$.

\section{Nutrient digestibility}

Nutrients digestibility coefficients of experimental rations are presented in (Table 2). There were significant differences $(\mathrm{P}<0.05)$ in all nutrients digestibility coefficients among experimental rations. The highest value of OM digestibility was recorded with T2 compared with T1 (control), the figure recorded 77.01 vs $72.31 \%$ respectively. While the lowest one was observed with T4 (ureated SBTS 0.50 unchopped).

These results can explained in light of chemical composition, urea addition, mechanical treatment and the characteristics of forage. These results are agree with those finding by Ahmed et al. (2003) who found that the digestibility of DM and OM, increased with elevating the level of corn Stover silage in ration. The digestibility of $\mathrm{CP}, \mathrm{CF}$ and $\mathrm{EE}$ were higher in $\mathrm{T}_{1}$ than other groups. The NFE digestibility was higher and best in all treatments of treated SBTS compared with control one .The rations containing SBTS $0.25 \% \mathrm{U}$ were high digesion coefficients compared with ration containing SBTS $0.5 \%$ U. Also, the differences between rations containing SBTS $0.25 \% \mathrm{U}$ and control ration were not significant in most nutrient digestibilty except in NFE. These results are in agreement with obtained by Bendary et al . (2000) who found that no significant differences among expermental ration in digestability coefficient of all nutrients when cow fed rations containing differet forms of sugar beet tops and berseem silage compared with those fed dry summer ration . 
Deraz et al.

Table (2). Nutrients digestibility coefficients and nutritive values for rams fed different experimental rations.

\begin{tabular}{cccccc}
\hline Item & T1 & T2 & T3 & T4 & T5 \\
\hline Digestibility coefficients & & & & & \\
DM & $69.28 \pm 1.14^{\mathrm{a}}$ & $71.29 \pm 2.06^{\mathrm{a}}$ & $68.31 \pm 1.89^{\mathrm{a}}$ & $61.72 \pm 1.24^{\mathrm{b}}$ & $67.04 \pm 4.15^{\mathrm{a}}$ \\
OM & $72.31 \pm 1.09^{\mathrm{bc}}$ & $77.01 \pm 1.48^{\mathrm{a}}$ & $75.53 \pm 1.50^{\mathrm{ab}}$ & $69.38 \pm 2.88^{\mathrm{c}}$ & $72.75 \pm 3.59^{\mathrm{bc}}$ \\
CP & $72.00 \pm 1.22^{\mathrm{a}}$ & $68.82 \pm 1.24^{\mathrm{ab}}$ & $68.06 \pm 1.48^{\mathrm{ab}}$ & $60.34 \pm 3.35^{\mathrm{c}}$ & $64.95 \pm 3.92^{\mathrm{b}}$ \\
CF & $84.16 \pm 0.68^{\mathrm{a}}$ & $77.90 \pm 2.68^{\mathrm{b}}$ & $80.15 \pm 1.44^{\mathrm{ab}}$ & $72.34 \pm 2.02^{\mathrm{c}}$ & $73.09 \pm 3.86^{\mathrm{c}}$ \\
EE & $83.98 \pm 2.41^{\mathrm{a}}$ & $75.99 \pm 1.61^{\mathrm{bc}}$ & $81.14 \pm 3.76^{\mathrm{ab}}$ & $73.60 \pm 3.42^{\mathrm{c}}$ & $79.38 \pm 0.73^{\mathrm{abc}}$ \\
NFE & $67.57 \pm 1.26^{\mathrm{d}}$ & $79.18 \pm 1.24^{\mathrm{a}}$ & $76.23 \pm 1.59^{\mathrm{ab}}$ & $70.94 \pm 3.03^{\mathrm{cd}}$ & $74.49 \pm 3.38^{\mathrm{bc}}$ \\
Nutritive values & & & & & \\
TDN & $66.57 \pm 1.00^{\mathrm{a}}$ & $64.53 \pm 1.32^{\mathrm{a}}$ & $63.08 \pm 1.26^{\mathrm{a}}$ & $58.53 \pm 2.42^{\mathrm{b}}$ & $57.59 \pm 2.62^{\mathrm{b}}$ \\
DCP & $8.23 \pm 0.14^{\mathrm{c}}$ & $9.91 \pm 0.18^{\mathrm{a}}$ & $9.91 \pm 0.22^{\mathrm{a}}$ & $8.80 \pm 0.49^{\mathrm{bc}}$ & $9.48 \pm 0.50^{\mathrm{ab}}$ \\
\hline a,b,c,d
\end{tabular}

\section{Feeding values}

Highly significant differences $(\mathrm{P}<0.01)$ were detected among experimental rations concerning TDN and DCP. The highest values were recorded by T1 for TDN $(66.75 \%)$, while the lowest TDN value was found in T5 (57.59\%). However the highest value of DCP was recorded by T3 and T2, but the lowest one was found in T1 (control), recording (9.91 vs 8.23) respectively.

No significant differences between $\mathrm{T} 1$ and $\mathrm{T} 2$, and $\mathrm{T} 3$ were detected in TDN. Bendary et al . (2000)reported that no significant differences in nutritve value as (TDN for rations containing different forms of sugar beet tops and berseem silage compared with control ration. These results agreed with those obtaiend by Ahmed et al ., ( 2003) and Eweedah (1986) who reported that the DCP value was higher in sugar beet tops silage. Also, these results were in accordance with Gaafer et al. (2011) who found that DCP value increased with increasing level of sugar beet tops silage in the rations .

\section{Nitrogen balance}

Data in Table (3) indicated that significant defferences $(\mathrm{P}<0.05)$ among experimental treatments in total nitrogen intake (TNI), fecal nitrogen (FN), urinary nitrogen(UN), total nitrogen excretion(TNE), nitrogen balance (NB) and nitrogen absorbed (NAB).

Table (3) Nitrogen balance and nitrogen absorption for different treatments of experimental rations.

\begin{tabular}{lccccc}
\hline Item & $\mathrm{T} 1$ & $\mathrm{~T} 2$ & $\mathrm{~T} 3$ & $\mathrm{~T} 4$ & $\mathrm{~T} 5$ \\
\hline Total N intake & $21.92 \pm 0.00^{\mathrm{c}}$ & $28.18 \pm 0.49^{\mathrm{ab}}$ & $27.52 \pm 2.10^{\mathrm{b}}$ & $28.25 \pm 0.94^{\mathrm{ab}}$ & $30.31 \pm 1.05^{\mathrm{a}}$ \\
Fecal N & $6.15 \pm 0.27^{\mathrm{c}}$ & $8.80 \pm 0.50^{\mathrm{b}}$ & $8.75 \pm 0.48^{\mathrm{b}}$ & $11.23 \pm 1.26^{\mathrm{a}}$ & $11.39 \pm 1.57^{\mathrm{a}}$ \\
Urinary N & $3.27 \pm 0.29^{\mathrm{c}}$ & $6.07 \pm 0.37^{\mathrm{a}}$ & $4.30 \pm 0.35^{\mathrm{b}}$ & $3.38 \pm 0.74 \mathrm{~b}^{\mathrm{c}}$ & $4.35 \pm 0.56^{\mathrm{b}}$ \\
Total N excretion & $9.42 \pm 0.09^{\mathrm{b}}$ & $14.87 \pm 0.83^{\mathrm{a}}$ & $13.05 \pm 0.22^{\mathrm{ab}}$ & $14.61 \pm 1.98^{\mathrm{a}}$ & $15.74 \pm 1.63^{\mathrm{a}}$ \\
$\mathrm{N}$ balance & $12.50 \pm 0.09^{\mathrm{b}}$ & $13.31 \pm 0.37^{\mathrm{ab}}$ & $14.47 \pm 2.03^{\mathrm{a}}$ & $13.64 \pm 1.18^{\mathrm{ab}}$ & $14.57 \pm 1.10^{\mathrm{a}}$ \\
$\mathrm{N}$ absorbed & $15.77 \pm 0.27^{\mathrm{b}}$ & $19.38 \pm 0.01^{\mathrm{a}}$ & $18.77 \pm 1.63^{\mathrm{a}}$ & $17.02 \pm 0.63^{\mathrm{ab}}$ & $18.92 \pm 0.71^{\mathrm{a}}$ \\
\hline a,b,c Means denoted within the same row with different superscripts are significantly differ at $P<0.05$.
\end{tabular}

The values of (TNI), (FN), (UN) and (TNI) in control treatment were lower than other treatments, these results were in accordance with proximate analysis. The highest value of nitrogen balance (NB) was recorded by T5 (14.57)., while the intermediate values were observed byT2,T3andT4.Meanwhile control treatment was the lowest value of $\mathrm{NB}(12.50)$. Also the figures of(NAB) showed (T1)the lower value than other treatments.

The results of nitrogen balance (NB) and nitrogen absorbed (NAB)were conjugated with DCP (Table 2). Protein of rations could be more efficiently utilized either with rations containing silage than control ration.In this respect, Gunter et al., ( 1998) and Ghanem et al.,( 2000) came to the same conclusion with lambs and goats fed silage with feed mixture. 


\section{Feeding trail}

\section{Average daily gain}

Groth performance of lambs fed different rations are presented in Table (4). Higher final weight, total gain and daily gain were reicorded by ration contains SBTS than control ration, also the ration contain SBTS( U .0250\%) higher than rations contain SBTS $((0.5 \%)$. However this deferences were insignificant and differences $(\mathrm{p}<0.05)$. These results may be due to the suitable protein and energy contents and efficient utilization of treated SBTS and its rumen fermentation products, volatile fatty acids, NH3 and microbial protein (EL- Badawy., 1994). These results are inagreement with those obtained byEL-Nahas et al., (2009) showed that, feeding rations containing sugar beet tops silage and corn Stover silages increased final body weight, total gain and daily gain. Similar findings by Bendary et al. (1992 and 1999)who showed that live body weight gain for calves feeding ration containing sugar beet tops (silage or dried) and CFM were higher than calves fed rice straw, hay and concentrat mixture. Charmeley (2001) found thay there is aquadratic relationship between silage protein solubility and body weight gain. Initialy, increasing solubility leads to increases in weight gain. However, as solibilty increases above $475 \mathrm{~g} / \mathrm{Kg}-1$ total $\mathrm{N}$ then gains decline markedly.

Table (4). Growth Performance and feed conversion for lambs fed different experimental rations.

\begin{tabular}{|c|c|c|c|c|c|}
\hline Item & $\mathrm{T} 1$ & $\mathrm{~T} 2$ & T3 & $\mathrm{T} 4$ & T5 \\
\hline Initial weight $(\mathrm{kg})$ & $19.75 \pm 1.06$ & $19.75 \pm 0.48$ & $20.00 \pm 0.59$ & $20.00 \pm 0.56$ & $21.00 \pm 0.57$ \\
\hline Final weight (kg) & $38.88 \pm 0.81$ & $40.63 \pm 0.60$ & $40.81 \pm 0.61$ & $39.25 \pm 0.45$ & $40.38 \pm 0.60$ \\
\hline Total gain $(\mathrm{kg})$ & $19.13 \pm 0.55$ & $20.88 \pm 0.89$ & $20.81 \pm 0.51$ & $19.25 \pm 0.93$ & $19.38 \pm 1.13$ \\
\hline Daily gain $(\mathrm{g})$ & $159.42 \pm 4.57$ & $174.00 \pm 7.38$ & $173.42 \pm 4.22$ & $160.42 \pm 7.72$ & $161.46 \pm 9.44$ \\
\hline DM intake $(\mathrm{g})$ & $134.43 \pm 0.04^{\mathrm{a}}$ & $121.47 \pm 0.00^{\mathrm{b}}$ & $118.28 \pm 0.00^{\mathrm{c}}$ & $134.28 \pm 0.00^{\mathrm{a}}$ & $131.83 \pm 0.00^{\mathrm{a}}$ \\
\hline TDN intake & $89.46 \pm 0.00^{\mathrm{a}}$ & $78.38 \pm 0.00^{\mathrm{b}}$ & $76.62 \pm 0.00^{c}$ & $78.65 \pm 0.00^{\mathrm{b}}$ & $75.92 \pm 0.00^{c}$ \\
\hline DCP intake & $11.06 \pm 0.00^{\mathrm{d}}$ & $12.04 \pm 0.00^{\mathrm{c}}$ & $12.21 \pm 0.00^{\mathrm{b}}$ & $11.82 \pm 0.00^{c}$ & $12.41 \pm 0.00^{\mathrm{a}}$ \\
\hline \multicolumn{6}{|l|}{ Feed Conversion } \\
\hline $\mathrm{DM} \mathrm{kg} / \mathrm{kg}$ gain & $7.03 \pm 0.22^{\mathrm{a}}$ & $5.82 \pm 0.25^{\mathrm{b}}$ & $5.68 \pm 0.14^{\mathrm{b}}$ & $6.98 \pm 0.40^{\mathrm{a}}$ & $6.80 \pm 0.41^{\mathrm{a}}$ \\
\hline $\mathrm{TDN} \mathrm{kg} / \mathrm{kg}$ gain & $4.68 \pm 0.15^{\mathrm{a}}$ & $3.75 \pm 0.16^{\mathrm{b}}$ & $3.68 \pm 0.09^{b}$ & $4.09 \pm 0.24^{\mathrm{b}}$ & $3.92 \pm 0.23^{\mathrm{b}}$ \\
\hline DCP kg / kg gain & $0.58 \pm 0.02$ & $0.58 \pm 0.62$ & $0.59 \pm 0.01$ & $0.61 \pm 0.04$ & $0.64 \pm 0.04$ \\
\hline
\end{tabular}

\section{Feed intake}

There were significant differences $(\mathrm{P}<0.01)$ in feed intakes as DM, TDN and DCP among treatments. Lambs fed T2 and T3 recorded the lower feed intake as DM than control ration, while lambs fed control ration recorded the highest value for feed intake as TDN however, feed intake as DCP has lower than other treatments .

These results are in agreement with those obtained by Bendary et al. (1999) who found that feeding growing calves on ration containing sugar beet tops silage reduced the intake of DM and TDN .However , Gaafer et al . (2011) found that the DCP intake increased ( $\mathrm{p}<0.05 \%)$ with increaing level of SBTS in the ration, but the intake of DM and TDN decreased significant $(\mathrm{p}<0.5 \%)$.

\section{Feed conversion}

There were significant differences $(\mathrm{P}<0.05)$ in feed conversion among lambs fed the different experimental rations in Table (4). Feed conversion improved by feeding rations containing treated SBTS. Lambs fed T2 and T3, showed the best conversion as DM and TDN compared with those fed control ration $(\mathrm{T} 1)$. No significant differences $(\mathrm{P}<0.05)$ in conversion as DCP among lambs fed different diets containing different portions of treated SBTS. These results are in accordace with these obtained by Bendary et al . (1992 and 1999) who found that better feed efficiency attained by feeding growing calves in ration containing SBTS compared with control ration .Suliman et al. (2013)showed that the best feed conversion so as TDN or DCP that for diet containing CFM+SBTS compared with control diet(containing $\mathrm{CFM}+$ berseem hay). Overall, the insignificant differences for lambs performance between the chopped and unchopped, these results agree with thise obtained by Mostafa et al. (1995) who found that the differences between the chopped and unchopped berseem silage with 5\% molasses were minimal and not significant in most performance triats. 


\section{Deraz et al.}

\section{Economical efficiency}

Economic efficiency illustrated in Table (5) revealed that the total cost of feeding for lambs fed the control diet (T1) was higher (294.12 LE) compared with those fed on T2, T3, T4 and T5, being 254.43, $255.16,278.68$ and 279.42 LE,respectively. Moreover, lambs fed diets containing ureated sugar beet tops silages (T2, T3, T4 and T5) recorded the highest daily weight gain compared with control (T1).the figures were $20.88,20.81,19.25$ and $19.38 \mathrm{~kg}$ body weight gain vs. $19.13 \mathrm{~kg}$ for T1. Therefore, the lowest feed cost and the best weight gain equal the best revenue and better economic efficiency which showed by lambs fed diets containing ureated sugar beet tops T2, T3, T5 and T4 compared with T1 (Table 5). These results may be due to the reduce of the quantity of high expensive concentrate feed mixture, increasing daily weight gain with diets containing sugar beet tops. These results are in accordance with these obtained by (Ghanem et al. 2000 ; Ahmed et al. 2003 and El-Nahas et al 2009) who indicated that feeding growing calves in ration containing sugar beet tops silage reduced the feed coast per $\mathrm{kg}$ gain and subsequently increased economical efficiency.

Table (5). Feed cost and economical efficiency of different experimental groups.

\begin{tabular}{lccccc}
\hline Economical evaluation & T1 & T2 & T3 & T4 & T5 \\
\hline Total kg DMI of CFM & 104.49 & 94.11 & 94.43 & 100.74 & 100.48 \\
Total DMI of W.S. Or SBTS & 29.9 & 27.36 & 23.85 & 33.54 & 31.35 \\
Total feed intake kg DM & 134.39 & 121.47 & 118.28 & 134.28 & 131.83 \\
Cost of total feed intake LE $(\mathrm{b})$ & 294.12 & 254.43 & 255.16 & 278.68 & 279.42 \\
Price of kg LBW LE & 22.00 & 22.00 & 22.00 & 22.00 & 22.00 \\
Total gain & 19.13 & 20.88 & 20.81 & 19.25 & 19.38 \\
Price of total gain (a) & 420.86 & 457.82 & 453.86 & 423.50 & 426.36 \\
Revenue & 126.74 & 203.39 & 198.70 & 144.82 & 146.94 \\
Economical efficiency $(\mathrm{y})$ & 0.43 & 0.80 & 0.78 & 0.52 & 0.53 \\
Where: Economic efficiency, $y=\{(a-b) / b)\}$, where a selling cost the obtain gain and b = feeding cost of this gain.
\end{tabular}

\section{CONCLUSION}

It could be concluded that $\mathrm{T} 2$ and $\mathrm{T} 3$ showed an improvement in approximate analysis and experimental rations, digestibility, nutritive value, nitrogen balance, growth performance and economical efficiency. Therefore, it could be recommended that $(0.25 \%)$ ureated sugar beet tops silages chopped or unchopped can be used for lambs feeding.

\section{REFERENCES}

A.O.A.C. (1999). Association of Official Analytical Chemists. Official Methods of Analysis, 16th Ed. Published by the A.O.A.C. International Gaithersburg, MD., p. 111.

Agriculture Economics (2015). Agriculture Economics, part 1 pull. By Agric. Res.Center, Ministry of Agriculture , Egypt.

Ahmed, B.M.; H.T. Taie; M.M. Bendary and K.F. Abd El-Lateif (2003). Influence of dietary corn silage on digestibility, performance and economical efficiency of dairy cattle. Egyptain J. Nutr. and Feeds (Special Issue) $6: 587$.

Bendary, M.M., A.M. Mahmoud; I.S. Koriet, E.M. Abdel-Raouf and S.A. Awadalla (1992). Nutritional studies on using SBTS in animal feding. 4. Fattening ferisian calves on different forms of SBTS. J. Agric. Sci., Mansoura Univ., 17 (9): 28771-2880.

Bendary, M.M., M.M.Mohamed ,G.H.A.Ghanim and I.A.Abou-Selim.(1996). Nutritional studies on using sugar beet tops in animal feeding .5.Performance of lactating cows fed dried sugar Friesian beet tops and its silage.Egyptin j.anim.prod.,33,suppl.issue,nov.199-206.

Bendary, M.M. and M.A. Younis 1997. Evluation of Maize Stalks for feeding dairy cows. Egyptian J. Appl.Sci., 12:11. 
Bendary, M.M.;M.M. Mohamed and Sayed M.M. Ahmed (1999). Nutritional studies on using sugar beet tops in animal feeding 6- Performance of growing calves fed dried sugar beet tops and its silage. Egyptian J. Nutrition and Feeds, 2 (special Issue) : 167.

Bendary, M.M.; S.A. El-Ayuoty; F.H.H. Farrage; A.M.A. Mohi El-Din and F.F.M. Khalil (2000). Productive performance of lactating cows fed rations containing different forms of sugar beet tops and berseem silage. Proc. Conf. Anim. Prod. In The $21^{\text {th }}$ Century, Sakha, 18-20 April,: 255-265.

B"ohme, H., K. Aulrich, R.R. Daenicke and G. Flachowsky (2001). Genatically modified foods in animal nutrition. Glufosinate tolerant sugar beet (roots and silage ) and maize grains for ruminant and pigs. Arich Animal Nutr. Arch. Fur Tierernahrung, 54 81;167-168 .s; 197-207 .

Charmley (2001). Towards improved silage quality -Areview, Can. J. Anim. Sci., 81:157-168.

Duncan, D.B. (1955). Multiple range and multiple F tests. Biometrics, 11:1042.

El-Badawy, A.Y. (1994). Effect of dietry roughage levels on the lactation performance of Egyptain goats, Egyptain J. Anim. Prod., 31: 111-124.

Eweedah, N.M. (1986). Some nutritional studies on using sugar beet by-products in animal feeding. M.Sc. Thesis, Fac. Agric., Kaf El-Sheikh, Tanta Univ.

El-Nahas, H.M.; I.M.E. Shakweer; H.M.A. Gaafar and R.M. Abou-Aiana (2009). Productive performance and semen physical characteristics of Friesian calves fed different proportions of sugar beet tops and corn stover silages. Egyptian. J. Nutrition and Feeds, 12 (3): Special Issue: 193-204.

Gaafaar, H.M.A., E.M. Abdel-Rouf; M.M. Bendary; G.H. Ghanem and K.F. El-Rridy (2011). Productive performance of lactating buffaloes fed ration containing sugar beet tops and corn silages. Iranian $\mathrm{J}$. Applied Animal Science, 1(2): 117-123.

Gunter, S.A., M.I. Galyean and K.J. Malcolmcallis (1998). Factors influencing the performance of lot steers limit-feed high concentrate diet. Prod. Anim. Sci., 12; 167-175.

Ghanem, G.H.A.; E.A. Amer and F.A. El-Zeer (2000). Evluation of Using Maize Stover Silage by sheep. J. Agric. Res. Tanta Univ., $26: 591$.

Haustein, S. (2003). Feeding vaules of Silages; http:// wwwl.Agric.Gov.ab.Ca/\$department/deptdocs.Nsf/all/for4907.

MARSS (1997). Ministry of Agriculture and Reclaimed Sand Soil; Agriculture Research Center ; Animal Production Research Institute. Book of Application and Scientific Animal Nutrition, $1^{\text {st }}$ Edition, 1997.

Mohi El-Din, A.M.A. (1998). Studies on Cattle Production "Nutritional Studies on the use of Sugar beet by-Products in feeding lactating Cows", Ph.D. Thesis, Fac. Agric. Mansoura Univ.

Mostafa , M.R.H .; M.F. El-Says; K.F.I. Etman and M.K. Hathout (1995). Performance of lambs fed alfalfa hay or berseem silages. Proc. $5^{\text {th }}$ Sci. Conf. Animal Nutrient, Vol. 1 p: 165-177.

Stanacev Vidica, V.D. (2002). The feed sugar minimum as precandition of good quality silage. Acta Agric. Serbiea, 13: 41-48 .

Suliman, A.I.A. (2001). Studies on using some green forage in sheep feeding. Ph.D. Sci., Fac. Agric. Anim. Prod. Dept. Minia Univ.

Suliman, A.I.A., S.M.S. Moustafa, and K.M. Marzouk (2004). Effect of feeding silage of berseem mixed with some agriculture by-products on digestibility and performance of sheep. Minia J. Agric. Res. \& Development, 24(4): 737-752.

Suliman, A.I.A., A.A. Baiomy and M.A.A. Awad-Allha (2013). Productive performance of growing lambs fed silages of sugar cane tops, sugar beet leaves and green maize stem. Egypt. J. Anim. Prod. 50 (2): 59-67.

SAS Institute (2003). SAS Users Guide. Version 9.1 SAS Institute Inc., carry, NC.

Taie, H.T. (1998). Effect of dietary levels of protein and fiber on digestion, performance and carcass traits of sheep. Egypt. J. Nutr. and Feeds, 1: (1): 28-32.

Ximena Valderrama, 1. and G. Rene Anrique (2011). In situ ruminant degerdation kientics of high-protien forage crops temperate climates. Chilean J. Agric. Res., 71(4): 572-577. 


\section{Deraz et al.}

\section{تظذية الاغنام بسيلاج عروش بنجر في العروة الصيفي}

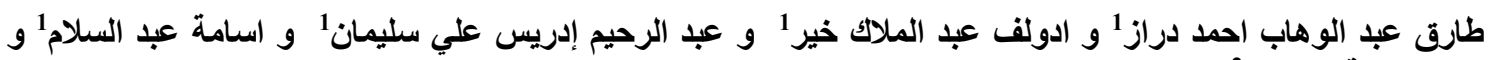 احمد اسامة الاشهب}

1قسم تظذية الحيوان- معهل بحوث الإتتاج الحيواني ـ مركز البحوث الزراعية ـ الدقي -الجيزة

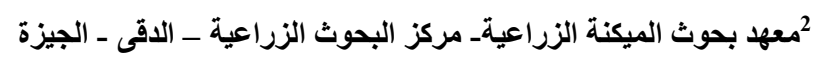

أجرى هذا البحث فى محطة بحوث الانتاج الحيوانى بملوى التابعة لمعهد بحوث الانتاج الديو انى لدراسة النمو ومعاملات الهضم

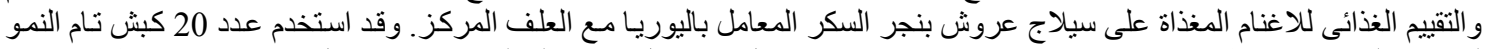

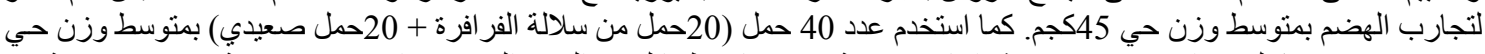

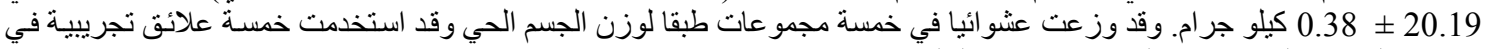
تجربني الهضم و النمو وكانت العلائق موز عة كالتالى :-

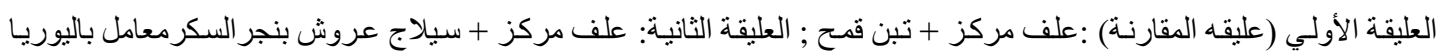

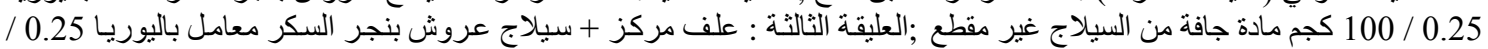

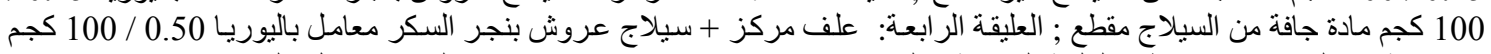

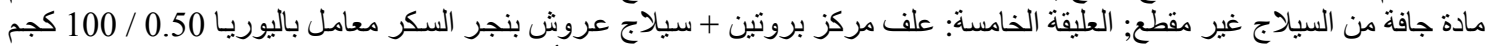

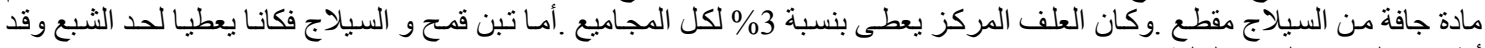

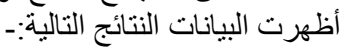
1- كانت العليقة الأولي (الدقارنة اعلى معنويا عند مستوى (0.05 ) بالنسبة لهضم البروتين الخام والألياف الخام والدهن وكذلك المركبات الكلية المهضومة عن باقي المعاملات.

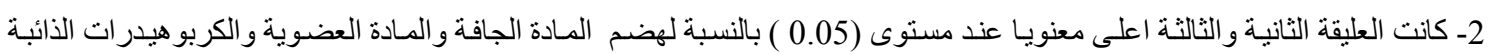
والبروتين مهضوم عن باقي المعاملات.

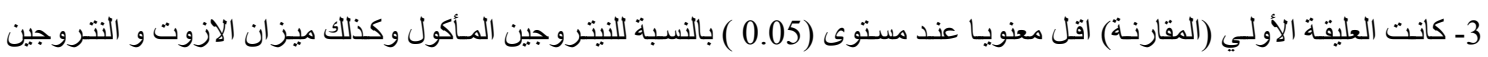
المنص عن باقي المعاملات.

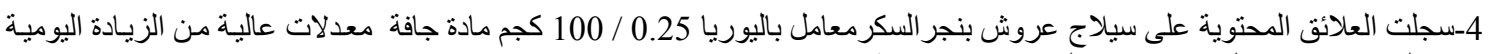
في الوزن عن باقي العلائق وكانت الفروق غير معنوية.

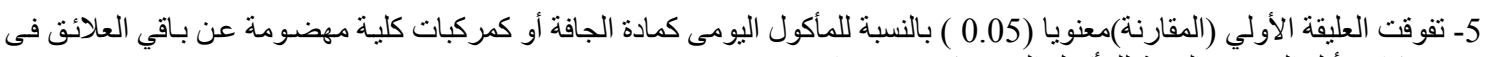

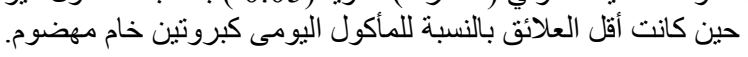

6-كانت الحملان المغذاة على العليقة الثانية والثالثة افضل فيى الكفائة التحويلية للغذاء كمادة الجافة أو كمركبات كلية مهضومة عن عن باقي الحملان .

7- كانت العليقة الثانية افضل العلائق من حيث الكفائة|الاقتصادية ثليها العلائق3 ثم 4 ثم 5 و كانت أقلهم فى الكفائة|الاقتصادية العليقة الأولي (المقارنة ) .

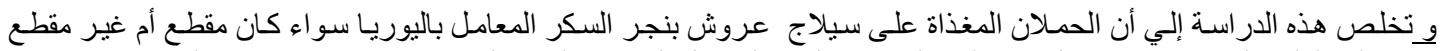

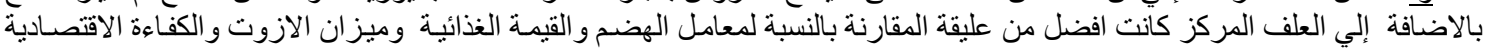

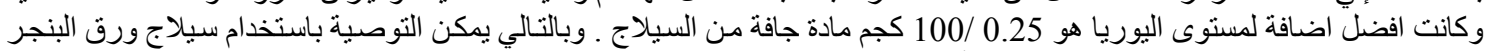
المعامل باليوريا بنسبة 0.25 / 100 في تغذية الأغنام . 